\title{
EFFICIENCY OF USING BIOFERTILIZATION IN REDUCING NITROGEN FERTILIZER APPLICATION AND THEIR EFFECT ON GERMINATION, GROWTH AND YIELD OF MAIZE (Zea mays L.)
}

Aml E. A. El-Saidy and F. I .Yousof

Department of Seed Tech. Res., Field Crops Res. Institute, ARC, Giza

\begin{abstract}
A laboratory study was designed to investigate the influence of seed inoculation treatments with cerialein (Azospirillum brasilense), phosphorein (Bacillus megaterium) and mixture from both on germination and seed vigor of maize (SH. 166 cultivar, yellow kernel) as compared with uninoculated seed during 2012 season. Also, field experiments were conducted to evaluate efficiency of Azospirillum brasilense $(\mathrm{Ab})$, Bacillus megaterium $(\mathrm{Bm})$ and mixture from both in reducing nitrogen fertilizer levels (120, 90, 60, $30 \mathrm{~kg} \mathrm{~N} / \mathrm{fed}$ and without $\mathrm{N}$ application as a control) and their effect on emergence, growth and yield during 2012 and 2013 seasons. The results indicated that seed inoculated with combination of Azospirillum brasilense \& Bacillus megaterium significantly increased seed vigor as compared with uninoculated seed. The results showed the role of Azospirillum brasilense \& Bacillus megaterium in enhancing and promoting germination, activation seed vigor and development of maize. The results revealed that seed inoculated with Azospirillum brasilense \& Bacillus megaterium and adding $90 \mathrm{~kg} \mathrm{~N} / \mathrm{fed}$ produced good growth and yield approaching $120 \mathrm{~kg} \mathrm{~N} / \mathrm{fed}$ without significant differences between both. The lowest values of growth and yield were obtained from the uninoculated treatment and without nitrogen fertilization. It could be concluded that seed inoculated with Azospirillum brasilense and Bacillus megaterium beside addition $90 \mathrm{~kg} \mathrm{~N} / \mathrm{fed}$ achieved high productivity of maize.

Keywords: Zea mays L., biofertilization, nitrogen fertilizer, germination, field emergence, growth and yield
\end{abstract}

\section{INTRODUCTION}

Nitrogen and phosphorus are essential nutrients required by both plants and microorganisms, their major physiological roles are the accumulation and release of energy during cellular metabolism (Marchner, 1995). In Egypt, chemical fertilizers, especially nitrogen fertilizer has become an economic problem for farmers because they become more expensive, in addition to its environment pollution. So, it was an urgent need to reduce chemical fertilizers and provide alternatives as biofertilizer technique. Increases in plant growth have been attributed either to nitrogen fixation by the associated bacteria or to an increase in the absorbing surface of the root system due to growth substances produced by the bacteria, inoculation of plants with Azospirillum could result in significant changes in various growth parameters such as increase in plant biomass, nutrient uptake, tissue $\mathrm{N}$ content, plant height, leaf size and root length of cereals (Bashan et al., 2004). Maize seed inoculation with Azospirillum lipoferum DSM 1691, Abrasilense DSM 1690 significantly enhanced seed germination and seedling 
vigor, bacterial treatments had a more stimulating effect on growth and development of plants and significantly increased plant height, 100 seed weight, number of seeds per ear and leaf area, the results also showed significant increase in ear and shoot dry weight of maize (Gholami et al., 2009 ).

Phosphorus is generally deficient in most natural soils, because it is fixed as water-insoluble iron and aluminum phosphates in acidic soils or calcium phosphate in alkaline soils (Singh and Kapoor, 1994). However, calcium phosphate, which is of low solubility, can be dissolved and made available to plants by soil rhizosphere microorganisms through the production of organic acids (Rodriguez and Fraga, 1999). The inoculation of seed with phosphate solubilizing microorganisms may alleviate this problem.

Therefore, a promising trend for increasing nitrogen and phosphorus availability to plants has been increased using combined inoculation of nitrogen fixing and P-dissolving organisms. There have been many successful attempts to improve plant development by using mixtures of Azospirillum and VA mycorrhiza (Alarcon et al., 2002). Similarly, the combined inoculation of Azospirillum and P-solubilizing bacteria was successfully used for plant N, P nutrition and growth yield (Belimov et al., 1995).

This study was aimed to evaluate the efficiency of inoculation with Azospirillum brasilense and Bacillus megaterium in reducing nitrogen fertilizer for alleviation soil pollution.

\section{MATERIALS AND METHODS}

Laboratory experiment was implemented at Seed Technology Research Unit Mansoura, Dakahlia Governorate, Seed Technology Research Department, Field Crop Research Institute, Agricultural Research Center during 2012 season to evaluate the effect of seed inoculation treatments with cerialein (Azospirillum brasilense), phosphorein (Bacillus megaterium) and combination of both on germination behavior and seedlings vigor of maize (SH. 166 cultivar) single hybrid cross 166 which is a yellow kernel. A completely randomized design with four replicates was used. Field experiments were conducted at the experimental Farm of Tag AL - Ezz, Agric. Res. Station, ARC, Dakahlia Governorate, Egypt during 2012 and 2013 seasons to evaluate efficiency using of biofertilization and nitrogen fertilizer levels and their interactions on growth and yield of maize (SH. 166 cultivar). A strip plot design as factorial with two factors at four replicates was used in each season and combining analysis for two seasons was done. The horizontal plots were devoted to the four biofertilizaion treatments, i.e. inoculated with Azospirillum brasilense (Ab), inoculated with Bacillus megaterium $(\mathrm{Bm})$, inoculated with mixture from Azospirillum brasilense \& Bacillus megaterium and uninoculated seed. The vertical plots were devoted to the nitrogen fertilizer levels $(120,90,60,30 \mathrm{~kg} \mathrm{~N} / \mathrm{fed}$ and without $\mathrm{N}$ application as a control). 


\section{Seed treatments:}

Seed sample of maize was divided into four parts. One part was inoculated with cerialein (Azospirillum brasilense). Second part was inoculated with phosphorein (Bacillus megaterium). Third part was inoculated with mixture from Azospirillum brasilense (Ab)\& Bacillus megaterium (Bm). Fourth part was uninoculated seed as a control. Using Arabic gum as sticker agent during inoculation seed with different biofertilization treatments. The rates of cerialein and phosphorein both $\left(10^{8} \mathrm{CFU} / \mathrm{mL}\right)$ were 120 and $300 \mathrm{~g}$ /fed, respectively for field experiments.

\section{Laboratory experiment:}

Four hundred seeds from each treatment were placed in eight sterilized Petri dishes $(15 \times 1.5 \mathrm{~cm})$ on Whatman No.1 filter paper that was moistened with $10 \mathrm{ml}$ of water. Each Petri-dish kept close together and incubated at $25 \pm 2{ }^{\circ} \mathrm{C}$, with a $12 \mathrm{~h}$ photoperiod and $70 \%$ relative humidity, then, four replications were used to evaluate subjected to standard germination test as the rules of International Seed Testing Association (ISTA, 1999).

\section{Seed and seedlings vigor characters:}

Counts of germinating seeds were taken daily up to 7 days after the start of germination. Speed germination index (SGI), germination rate (GR), Co-efficient of germination, germination percentage, root length $(\mathrm{cm})$,shoot length $(\mathrm{cm})$ and seedlings dry weight $(\mathrm{gm})$ were determined in this experiment.

1-SGI was calculated as described in the Association of Official Seed Analysis (AOSA, 1983) by following formula:

$$
\mathrm{SGI}=\frac{\text { number of germinated seed }}{\text { days of first count }}+\ldots+\frac{\text { number of germinated seed }}{\text { days of final count }}
$$

Seeds were considered germinated when the radicle was at least $2 \mathrm{~mm}$. long. 2- Germination rate (GR) was defined according to the following formula of Bartllett, 1937.

$$
G R=\frac{a+(a+b)+(a+b+c) \ldots \ldots(a+b+c+m)}{n(a+b+c+m)}
$$

Where $a, b, c$ are number of seedlings in the first, second and third count, $m$ is the number of seedlings in the final count and $n$ is the number of counts.

3- Co-efficient of germination (CG) was calculated using the following formula (Copeland, 1976).

$$
\text { Co-efficient of germination }=\frac{100\left(A_{1}+A_{2}+\ldots \ldots . . A_{n}\right)}{A_{1} T_{1}+A_{2} T_{2}+\ldots \ldots . . A_{n}}
$$

Where,

\footnotetext{
$A=$ Number of seeds germinated.

$\mathrm{T}=$ Time (days) corresponding to $\mathrm{A}$.

$\mathrm{n}=$ No. of days to final count.
} 
4- Germination percentage was defined as the total number of normal seedlings at the end of the test after seven days and then seedling characters were taken.

\section{Field experiments:}

The soil was clay loam and characterized by pH, 8; E.C, $3.0 \mathrm{dS} / \mathrm{m}$. wheat (Triticum aestivum L.) was the preceding winter crop in all seasons of experimentation. The experimental field well prepared through two ploughing, leveling, compaction, ridging and divided into the experimental units. Seeds of maize were inoculated with the bacterial as mentioned before. Uninoculated seeds as control (without biofertilization) were also included. Five-ridges of plot were prepared with ridge width and length space of 0.7 and $3.0 \mathrm{~m}$, respectively to gave $(3.5 \times 3.0) 10.5 \mathrm{~m}^{2}$ for plot area. Maize seeds were sown on $5^{\text {th }}$ and $15^{\text {th }}$ May in 2012 and 2013 seasons, respectively. Seeds were sown in hills spaced of $30 \mathrm{~cm}$ apart with two seed/hill at $5 \mathrm{~cm}$ depth at a rate of $10 \mathrm{~kg} / \mathrm{fed}$. At three leaves stage plants were thinned to one plant per hill. Nitrogen fertilizer in the form of urea $(46.5 \% \mathrm{~N})$ at the different rates under study $(120,90,60,30 \mathrm{~kg} \mathrm{~N} / \mathrm{fed}$ and without $\mathrm{N}$ application as a control) was added in two equal portions after 21 (after thinning to one plant /hill before the first irrigation) and 36 days from planting (before second irrigation). Calcium Superphosphate $\left(15.5 \% \mathrm{P}_{2} \mathrm{O}_{5}\right)$ and Potassium Sulphate $\left(48 \% \mathrm{~K}_{2} \mathrm{O}\right)$ was added at the rate of $200 \mathrm{~kg} / \mathrm{fed}$ and $50 \mathrm{~kg} / \mathrm{fed}$, respectively on the dry soil before ploughing. Other cultural practices for growing maize were conducted as recommended by Ministry of Agricultural and Land Reclamation.

\section{Studied characters}

\section{Field emergence, growth and yield characters:}

Field emergence percent was determined after 7 days from planting and emergence index was calculated using the formula of Scott et al., 1984:

$$
\mathrm{El}=\{\mathrm{TiNi} / \mathrm{S}\} \text {. }
$$

where $\mathrm{Ti}$ is the number of days after sowing, $\mathrm{Ni}$ is the number of seeds germinated on day $i$, and $S$ is the total number of seeds planted.

At harvesting time, the inner ridges were chosen from each plot to determine the plant height $(\mathrm{cm})$, ear leaf area $\left(\mathrm{cm}^{2}\right)$, plant dry weight $(\mathrm{g})$, ear length $(\mathrm{cm})$, ear diameter $(\mathrm{cm})$, ear weight $(\mathrm{g})$, number of rows/ear, number of grains/row and grain yield $(\mathrm{kg} / \mathrm{fed})$.

\section{Statistical analysis:}

All obtained data of characters were subjected to the statistical analysis according to the technique of analysis of variance (ANOVA) of completely randomized design and strip plot design for laboratory and field experiment, respectively, as described by Gomez and Gomez (1984).

\section{Seed and seedling vigor measurements:}

\section{RESULTS}

Seed germination percentage, speed germination index and germination rate of maize inoculated with Azospirillum brasilense (Ab) or Bacillus megaterium $(\mathrm{Bm})$ alone or in combination of both, are shown in Fig.1. Inoculation with mixture from Azospirillum brasilense and Bacillus megaterium enhanced germination $\%$, as compared with control 
(uninoculated seeds). In other words, germination percentage of control seeds was lower as compared with inoculated seed. Such results indicate that Azospirillum brasilense and Bacillus megaterium have promotion effects in early growth stages. Also, faster germination and early seedling growth were obtained by inoculated with mixture from Azospirillum brasilense and Bacillus megaterium as shown in speed germination index and germination rate characters supporting the potential role of bacterial growth regulators in enhancing germination rate and early development of plant structures. At contrary uninoculation maize seed with bacteria showed slower germination as compared with inoculated seed. The obtained results stated the role of biological fertilizers in stimulation and improvement field emergence and seedling vigor.
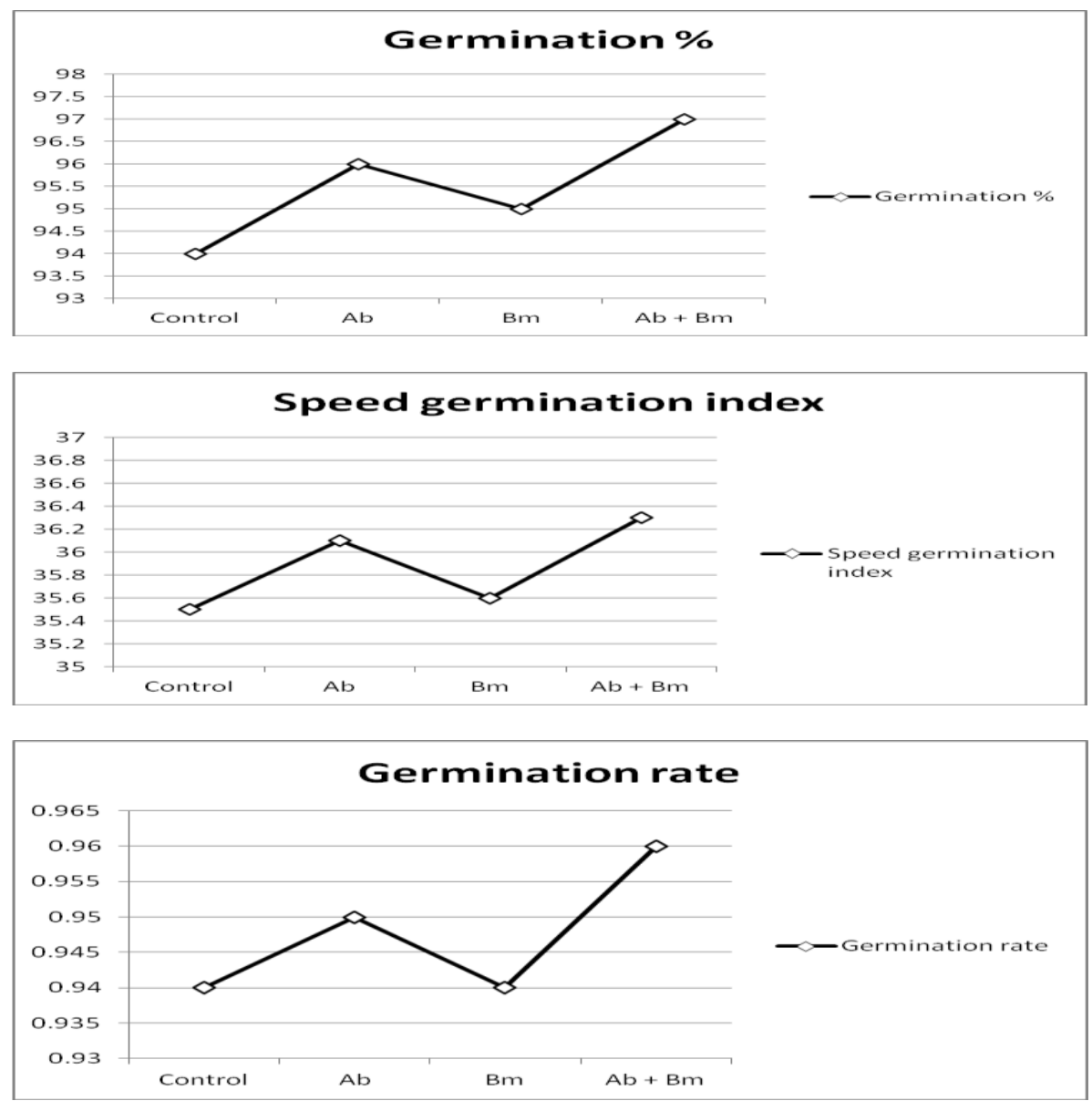

Fig.1: Germination \%, speed germination index and germination rate of maize seed as affected by inoculation with Azospirillum brasilense $(\mathrm{Ab})$, Bacillus megaterium $(\mathrm{Bm})$ and mixture of both. 
Fig. 2 showed increment in co -efficient of germination, field emergence and index emergence of maize seed inoculated with combination of Azospirillum brasilense \& Bacillus megaterium as compared with uninoculated seed. Hence, uninoculated seed recorded the lowest values of aforementioned characters. Increasing the speed of germination by inoculation seed with Azospirillum brasilense \& Bacillus megaterium led to longer root length, shoot length and heavier seedling dry weight as compared with uninoculated seed as illustrated in Fig.3.
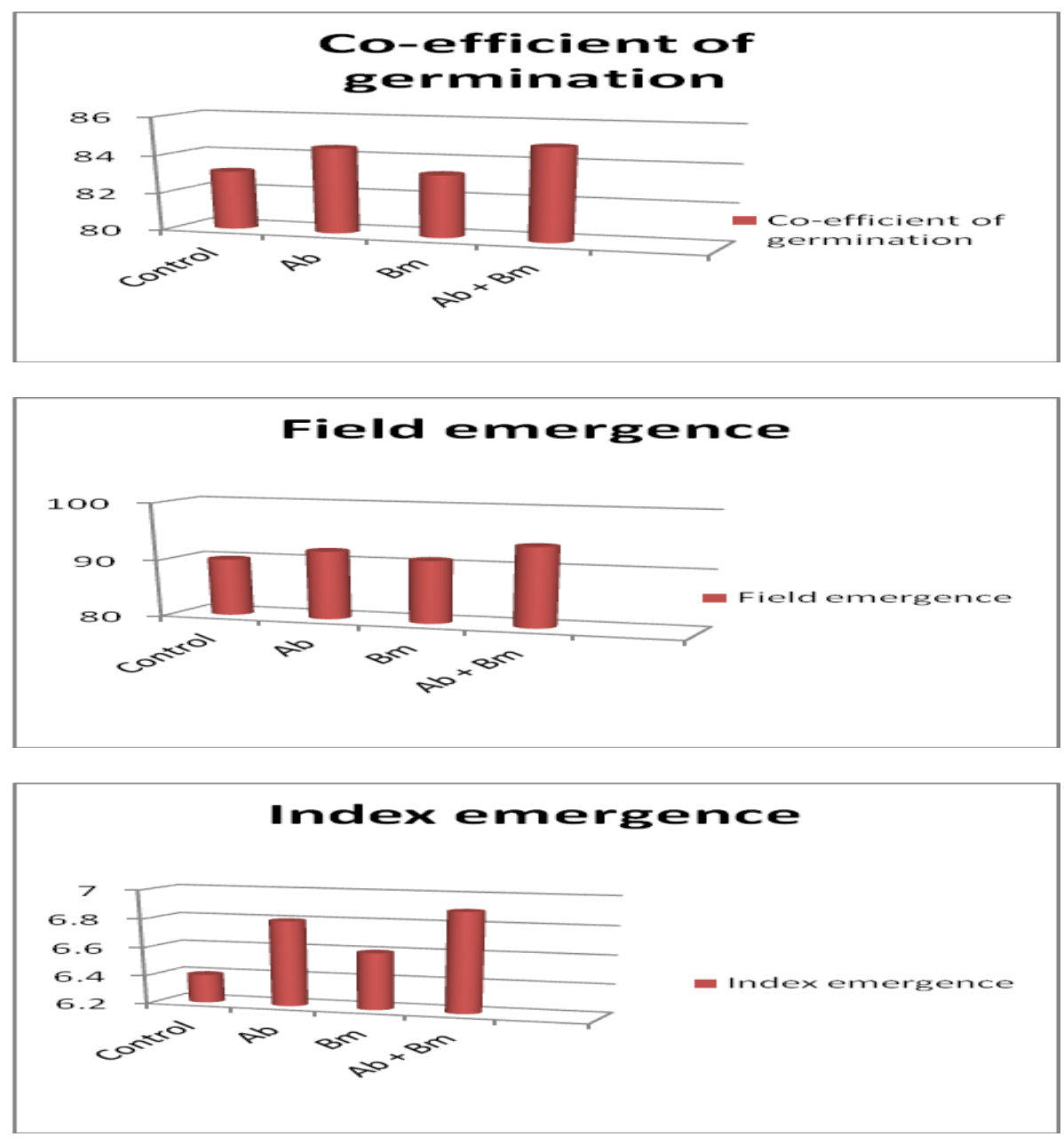

Fig.2: Co -efficient of germination, field emergence and index emergence of maize seed as affected by inoculation with with Azospirillum brasilense (Ab), Bacillus megaterium (Bm) and mixture of both. 

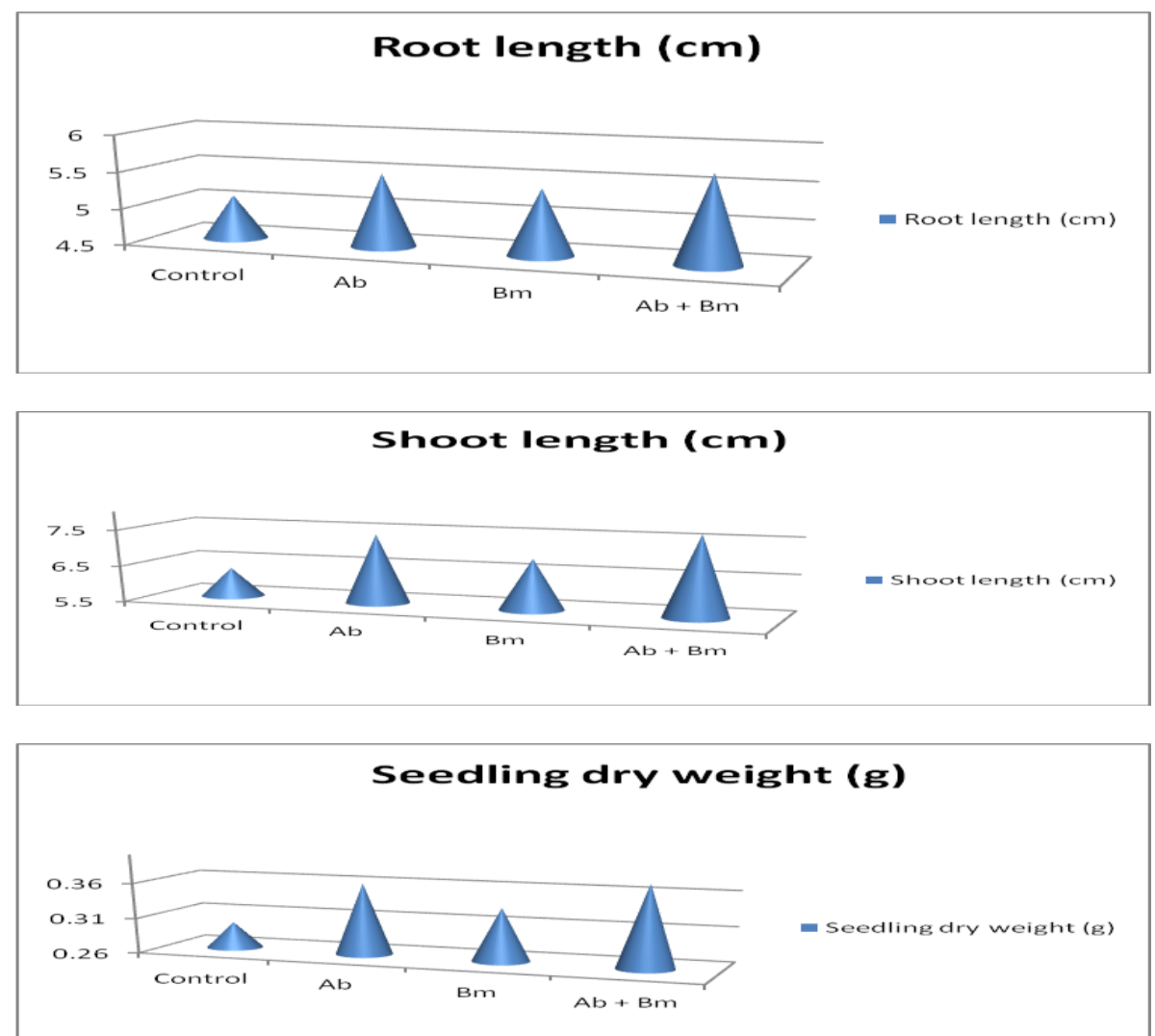

Fig.3: Root length $(\mathrm{cm})$, shoot length $(\mathrm{cm})$ and seedling dry weight $(\mathrm{g})$ of maize seed as affected by inoculation with with Azospirillum brasilense $(\mathrm{Ab})$, Bacillus megaterium $(\mathrm{Bm})$ and mixture of both.

\section{Field experiments:}

Results in Tables $(1,2$ and 3$)$ revealed that plant height $(\mathrm{cm})$, ear leaf area $\left(\mathrm{cm}^{2}\right)$, plant dry weight $(\mathrm{g})$, ear length $(\mathrm{cm})$, ear weight $(\mathrm{g})$, number of grains/row and grain yield ( $\mathrm{kg} / \mathrm{fed}$ ) significantly affected by biofertilizers inoculation of maize seed.

Whereas, the combination of Azospirillum brasilense \& Bacillus megaterium achieved the highest values of aforementioned characters of Tables (1, 2 and 3), followed by Azospirillum brasilense, then by Bacillus megaterium. Otherwise, uninoculated maize seed recorded the lowest values of all aforementioned characters as could be seen in Tables (1, 2 and 3 ). Regarding to nitrogen fertilizer effect, the full dose of nitrogen fertilization (120 kg N/fed) showed the best results of growth and yield attributes as shown in Tables (1,2 and 3), followed the application of $90 \mathrm{~kg} / \mathrm{fed}$ of nitrogen fertilizer. The lowest results of previously characters were obtained by (without nitrogen fertilizer) treatment, regarding the combined analysis. 
Table 1: Plant height $(\mathrm{cm})$, ear leaf area $\left(\mathrm{cm}^{2}\right)$ and plant dry weight $(\mathrm{g})$ characters of SH 166 maize cultivar as affected by biofertilization and nitrogen fertilizer levels in both seasons and combined data.

\begin{tabular}{|c|c|c|c|c|c|c|c|c|c|}
\hline \multirow{2}{*}{$\begin{array}{l}\text { Characters } \\
\text { Treatments and interactions }\end{array}$} & \multicolumn{3}{|c|}{ Plant height $(\mathrm{cm})$} & \multicolumn{3}{|c|}{ Ear leaf area $\left(\mathrm{cm}^{2}\right)$} & \multicolumn{3}{|c|}{ Plant dry weight $(\mathrm{g})$} \\
\hline & 2012 & 2013 & Comb. & 2012 & 2013 & Comb. & 2012 & 2013 & Comb. \\
\hline \multicolumn{10}{|l|}{$\begin{array}{l}\text { Biofertilization treatments } \\
\text { (B): }\end{array}$} \\
\hline Inoculation with $\mathrm{Ab}$ & 195.4 & 200.6 & 198.0 & 193.9 & 198.6 & 196.3 & 309.8 & 320.6 & 315.2 \\
\hline Inoculation with $\mathrm{Bm}$ & 191.0 & 198.6 & 194.8 & 186.7 & 193.1 & 189.9 & 308.5 & 316.7 & 312.6 \\
\hline Inoculation with $\mathrm{Ab} \& \mathrm{Bm}$ & 197.0 & 203.2 & 200.1 & 201.6 & 206.0 & 203.8 & 320.7 & 326.5 & 323.6 \\
\hline Uninoculation & 189.6 & 196.8 & 193.2 & 183.1 & $\frac{187.6}{* *}$ & 185.3 & 304.8 & 313.2 & 309.0 \\
\hline F. test & 09 & 18 & 14 & 13 & 26 & 23 & 12 & 23 & 18 \\
\hline \multicolumn{10}{|c|}{$\begin{array}{l}\text { Nitrogen fertilizer levels } \\
\text { (N): }\end{array}$} \\
\hline $120 \mathrm{~kg} \mathrm{~N} / \mathrm{fed}$ & $\begin{array}{l}210.0 \\
2035\end{array}$ & 214.0 & 212.0 & $\begin{array}{l}232.6 \\
2139\end{array}$ & $\frac{238.2}{2178}$ & $\frac{235.4}{215}$ & 337.6 & 344.4 & 341.0 \\
\hline$\frac{90 \mathrm{~kg} \mathrm{~N}}{60 \mathrm{~kg} \mathrm{~N}}$ & $\frac{203.5}{189.0}$ & $\frac{209.5}{196.0}$ & $\frac{206.5}{192.5}$ & $\frac{213.9}{181.9}$ & $\frac{217.8}{187.6}$ & $\frac{215.9}{184.8}$ & $\frac{327.8}{304.0}$ & $\frac{334.8}{310.0}$ & $\frac{331.3}{307.0}$ \\
\hline $30 \mathrm{~kg} \mathrm{~N} / \mathrm{fed}$ & 184.0 & 191.6 & 187.8 & 168.4 & 173.2 & 170.8 & 294.1 & 305.5 & 299.8 \\
\hline Without nitrogen fertilizer & 179.5 & 188.5 & 184.0 & 159.9 & 164.8 & 162.4 & 291.2 & 301.5 & 296.3 \\
\hline F. test & & & & & & & & & \\
\hline LSD at $5 \%$ & 0.8 & 2.8 & 0.9 & 1.1 & 3.8 & 1.5 & 1.1 & 3.5 & 1.2 \\
\hline Interactions & & & & & & & & & \\
\hline
\end{tabular}

Table 2: Ear length $(\mathrm{cm})$, ear diameter $(\mathrm{cm})$ and ear wight $(\mathrm{g})$ characters of SH 166 maize cultivar as affected by biofertilization and nitrogen fertilizer levels in both seasons and combined data.

\begin{tabular}{|c|c|c|c|c|c|c|c|c|c|}
\hline \multirow{2}{*}{$\begin{array}{l}\text { Characetrs } \\
\text { Treatments and interactions }\end{array}$} & \multicolumn{3}{|c|}{ Ear length $(\mathrm{cm})$} & \multicolumn{3}{|c|}{ Ear diameter $(\mathrm{cm})$} & \multicolumn{3}{|c|}{ Ear weight (g) } \\
\hline & 2012 & 2013 & Comb. & 2012 & 2013 & Comb. & 2012 & 2013 & Comb. \\
\hline \multicolumn{10}{|l|}{$\begin{array}{l}\text { Biofertilization } \\
\text { treatments (B): }\end{array}$} \\
\hline Inoculation with $\mathrm{Ab}$ & 22.1 & 23.3 & 22.7 & 14.6 & 14.6 & 14.6 & 140.5 & 146.1 & 143.3 \\
\hline Inoculation with Bm & 21.9 & 22.3 & 22.1 & 14.3 & 14.5 & 14.4 & 138.3 & 144.5 & 141.4 \\
\hline Inoculation with $\mathrm{Ab} \& \mathrm{Bm}$ & 23.0 & 23.8 & 23.4 & 14.6 & 14.8 & 14.7 & 142.0 & 148.0 & 145.0 \\
\hline Uninoculation & 21.8 & 22.2 & 22.0 & 14.3 & 14.5 & 14.4 & 135.5 & 143.9 & 139.7 \\
\hline $\mathrm{F}$. test & & & & NS & NS & NS & & & \\
\hline LSD at $5 \%$ & 0.4 & 0.6 & 0.6 & - & - & - & 0.8 & 1.2 & 1.2 \\
\hline \multicolumn{10}{|l|}{ Nitrogen fertilizer levels (N): } \\
\hline $120 \mathrm{~kg} \mathrm{~N} / \mathrm{fed}$ & 23.6 & 25.0 & 24.3 & 15.4 & 15.6 & 15.5 & 163.2 & 171.2 & 167.2 \\
\hline $90 \mathrm{~kg} \mathrm{~N} / \mathrm{fed}$ & 23.3 & 23.5 & 23.4 & 15.0 & 15.4 & 15.2 & 160.5 & 163.9 & 162.2 \\
\hline $60 \mathrm{~kg} \mathrm{~N} / \mathrm{fed}$ & 21.6 & 23.2 & 22.4 & 14.5 & 14.9 & 14.7 & 143.4 & 150.8 & 147.1 \\
\hline $30 \mathrm{~kg} \mathrm{~N} / \mathrm{fed}$ & 21.5 & 21.8 & 21.6 & 14.0 & 14.1 & 14.1 & 125.9 & 132.7 & 129.3 \\
\hline Without nitrogen fertilizer & 20.9 & 21.3 & 21.1 & 13.1 & 13.3 & 13.2 & 102.4 & 109.8 & 106.1 \\
\hline F. test & & & & & & & & & \\
\hline LSD at & 0.4 & 0.9 & 0.4 & 0.4 & 0.7 & 0.5 & 0.7 & 1.8 & 0.8 \\
\hline Interactions of $(\mathrm{B} \times \mathrm{N})$ & & & & NS & NS & NS & & & \\
\hline
\end{tabular}

${ }^{*}=$ significant ${ }^{\star \star}=$ high significant $\mathrm{NS}=$ Non significant 
Table 3: Number of rows/ear, number of grains/row and grain yield $(\mathrm{kg} / \mathrm{fed})$ characters of SH 166 maize cultivar as affected by biofertilization and nitrogen fertilizer levels in both seasons and combined data.

\begin{tabular}{|c|c|c|c|c|c|c|c|c|c|}
\hline Characters & \multicolumn{6}{|c|}{ Number of rows /ear Number of grains / rou } & \multicolumn{3}{|c|}{ Grain yield $(\mathrm{Kg} / \mathrm{fed})$} \\
\hline $\begin{array}{l}\text { Seasons } \\
\text { Treatments and interactions }\end{array}$ & 2012 & 2013 & Comb. & 2012 & 2013 & Comb & 2012 & 2013 & Comb. \\
\hline $\begin{array}{l}\text { Biofertilization treatments } \\
\text { (B): }\end{array}$ & & & & & & & & & \\
\hline Inoculation with $\mathrm{Ab}$ & 14.2 & 15.0 & 14.6 & 33.9 & 37.3 & 35.6 & \multicolumn{2}{|c|}{ 2827.7|2867.9 } & 2847.8 \\
\hline Inoculation with Bm & 13.0 & 15.0 & 14.0 & 33.8 & 37.2 & 35.5 & \multicolumn{2}{|c|}{2804.22850 .3} & 2827.2 \\
\hline Inoculation with $\mathrm{Ab} \& \mathrm{Bm}$ & 14.4 & 15.2 & 14.8 & 36.3 & 36.9 & 36.6 & \multicolumn{2}{|c|}{2860.02910 .4} & 2885.2 \\
\hline Uninoculation & 13.0 & 15.0 & 14.0 & 33.0 & 36.0 & 34.5 & \multicolumn{2}{|c|}{$2780.9 \mid 2824.7$} & 2802.8 \\
\hline F. test & NS & NS & NS & * & * & * & $* *$ & $2 *$ & $t_{\star \star}$ \\
\hline LSD at $5 \%$ & - & - & - & 0.1 & 0.2 & 0.2 & 7.5 & 11.0 & 10.5 \\
\hline Nitrogen fertilizer levels (N) & & & & & & & & & \\
\hline $120 \mathrm{~kg} \mathrm{~N} / \mathrm{fed}$ & 15.0 & 17.0 & 16.0 & 36.8 & 39.6 & 38.2 & \multicolumn{3}{|c|}{\begin{tabular}{|l|l|l|}
3120.4 & 3246.6 & 3183.5 \\
\end{tabular}} \\
\hline $90 \mathrm{~kg} \mathrm{~N} / \mathrm{fed}$ & 14.6 & 16.0 & 15.3 & 35.1 & 37.9 & 36.5 & \multicolumn{3}{|c|}{\begin{tabular}{|l|l|l|}
3110.5 & 3148.9 & 3129.7 \\
\end{tabular}} \\
\hline $60 \mathrm{~kg} \mathrm{~N} / \mathrm{fed}$ & 13.8 & 15.2 & 14.5 & 34.2 & 36.4 & 35.3 & \multicolumn{3}{|c|}{\begin{tabular}{|l|l|l|}
2820.8 & 2826.8 & 2823.8 \\
\end{tabular}} \\
\hline $30 \mathrm{~kg} \mathrm{~N} / \mathrm{fed}$ & 13.4 & 13.7 & 13.5 & 33.8 & 35.6 & 34.7 & \multicolumn{3}{|c|}{\begin{tabular}{|l|l|l|}
2702 & 2717.6 & 2709.8 \\
\end{tabular}} \\
\hline Without nitrogen fertilizer & 12.0 & 13.0 & 12.5 & 31.3 & 34.5 & 32.9 & \multicolumn{3}{|c|}{\begin{tabular}{|l|l|l|}
2342.5 & 2371.3 & 2356.9 \\
\end{tabular}} \\
\hline F. test & & & & & & & & & \\
\hline LSD at $5 \%$ & 0.8 & 0.9 & 0.8 & 0.1 & 0.3 & 0.1 & 6.8 & 16.4 & 7.0 \\
\hline Interactions of $(\mathrm{B} \times \mathrm{N})$ & NS & NS & NS & & & & & & \\
\hline
\end{tabular}

${ }^{\star}=$ significant ${ }^{\star \star}=$ high significant $\mathrm{NS}=$ Non significant

The interaction effects between biofertilizers and nitrogen fertilizers on plant height $(\mathrm{cm})$, number of grains/row and grain yield/fed $(\mathrm{kg})$ are shown in Fig.4.

It is clear that the nitrogen fertilizer level $(120 \mathrm{~kg} / \mathrm{fed})$ recorded the highest values of growth and yield measurement as could be noticed in Fig. 4. But, inoculation with combination of Azospirillum brasilense \& Bacillus megaterium and adding $90 \mathrm{~kg} \mathrm{~N} / \mathrm{fed}$ succeeded to be approximately equivalent it , at plant height and number of grains/row characters. However, no significant differences could be detected between the application $120 \mathrm{~kg}$ $\mathrm{N} / \mathrm{fed}$ level and $(90 \mathrm{~kg} \mathrm{~N} / \mathrm{fed}+$ combination of Azospirillum brasilense \& Bacillus megaterium) at grain yield/fed, regarding the interaction between biofertilization and nitrogen treatments. On the other direction, the interaction between both control treatments (uninoculation + without $\mathrm{N}$ application) recorded the lowest values of these characters as illustrated in Fig.4. 
(A)

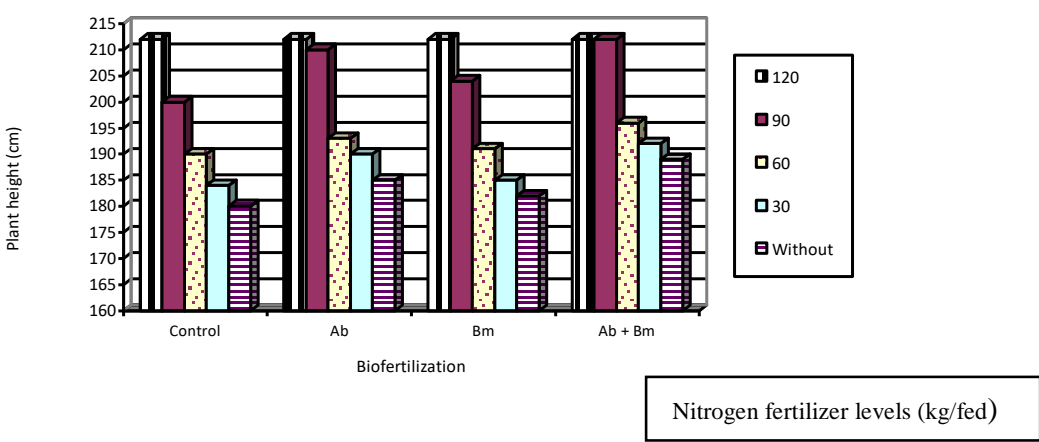

(B)

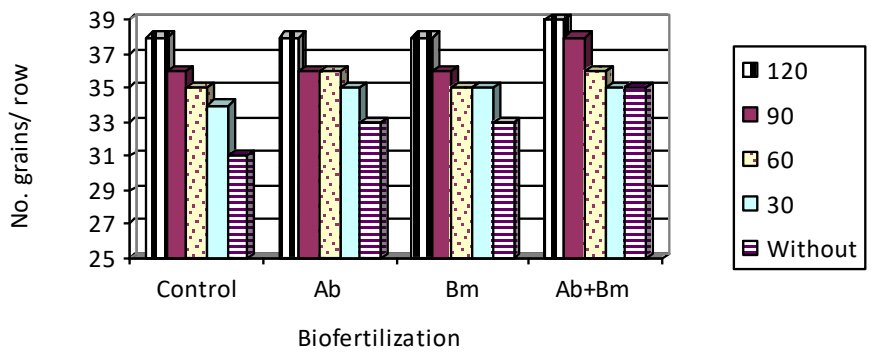

(C)

Nitrogen fertilizer levels (kg/fed)

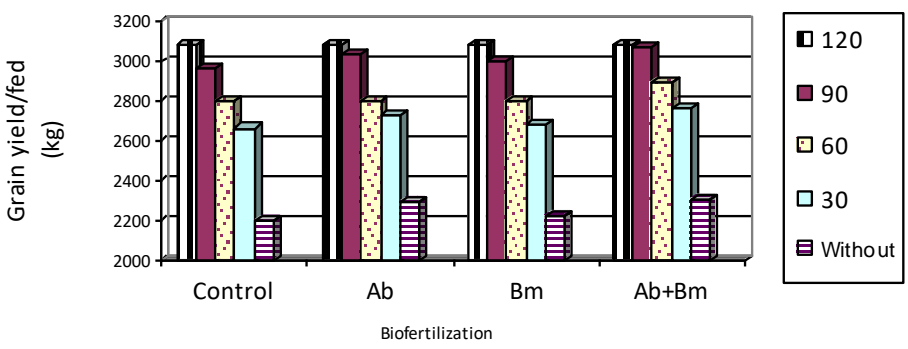

Fig. 4: Effect of the interactions between Azospirillum brasilense (Ab), Bacillus megaterium $(\mathrm{Bm})$ and nitrogen fertilizer levels on $(\mathrm{A})$ plant height $(\mathrm{cm}),(B)$ number of grains/row and (C) grain yield/fed $(\mathrm{kg})$ over both seasons. 


\section{DISCUSSION}

Results of this study indicated that inoculation maize seed of SH 166 cultivar with Azospirillum brasilense or Azospirillum brasilense \& Bacillus megaterium made enhancement in germination characters. It may be due to that Azospirillum spp. are known for their ability to produce plant hormones, as well as polyamines and amino acids in culture media (Thuler et al., 2003). Among these hormones, indoles, mainly indole-3-acetic acid (IAA); Spaepen et al., 2007), and gibberellins (GAs) of several kinds (Bottini et al., 2004) may play a larger role. These phytohormones alter metabolism and morphology of plants, leading to better absorption of minerals and water, consequently larger and healthier plants. The ability to form plant hormones is a major property of many microorganisms and plant growth-promoting bacteria (PGPB) in general and specifically, species of Azospirillum that stimulate and facilitate plant growth (Tsavkelova et al., 2006). These results are in accordance with (El-Komy ,2005) who reported that wheat inoculated with mixed inoculation azospirillum and bacillus exhibited high shoot dry weight.

Inoculation of maize seeds with mixed of Azospirillum brasilense \& Bacillus megaterium and $90 \mathrm{~kg} / \mathrm{fed}$ of nitrogen fertilizer resulted in a more visible increase nearing full dose from nitrogen fertilizer $(120 \mathrm{~kg} / \mathrm{fed})$ of growth and yield characters. Azospirillum inoculation had a significantly positive effect on the activity of the enzymes glutamine and glutamate synthesis (Saikia et al.,2007).Many studies show that the contribution of nitrogen fixation by Azospirillum to the plant is minimal and ranged, at best, from $5 \%$ to $18 \%$ of the total $N$ increase in the plant (Bashan et al., 2004). Measurement of nitrogen fixation after inoculation with $A$. lipoferum and $A$. brasilense in rice showed that the $\mathrm{N}$ derived from the atmosphere were $20.0 \%$ (A. lipoferum) and $19.9 \%$ (A. brasilense) in basmati rice and $58.9 \%$ (A. lipoferum) and $47.1 \%$ (A. brasilense) in super-basmati rice (Mirza et al., 2000).

The PSB Bacillus megaterium var. Phosphaticum Solubilising Bacteria play an important role through several ways, Bacillus megaterium promotes plant growth by producing 2-Pentylfuran which increased the growth(Zou et al.,2010). The principal mechanism for mineral phosphate solubilization is the production of organic acids, and acid phosphatases play a major role in the mineralization of organic phosphorous in soil (Rodríguez and Fraga, 1999).

The results indicated that the role of Azospirillum brasilense \& Bacillus megaterium in enhancing and promoting the germination stage by activation seed vigor and development of maize. This early studies reveal to the possibility of using these promising inoculants under field conditions.

So, it could be concluded that inoculation maize seed with Azospirillum brasilense \& Bacillus megaterium beside adding $90 \mathrm{~kg} / \mathrm{fed}$ of nitrogen fertilizer was good treatment to reduce chemical nitrogen fertilizer as well as satisfactory high growth and yield. 


\section{REFERENCES}

Alarcon, A.; F.T. Davies; J.N. Egilla; T.C. Fox; A.A. Luna and R. FerreraCerrato (2002). Short term effects of Glomus claroideum and Azospirillum brasilense on growth and root acid phosphatase activity of Carica papaya L. under phosphorus stress, Rev. Latinoam. Microbiol., 44: 31-37(C.F. Computer Search).

Association of Officinal Seed Analysis (AOSA) (1983).Seed Vigor Testing Handbook. Contribution No.32 to the Handbook on Seed Testing.

Bartllett, M.S. (1937). Some samples of statical method of research in agriculture and applied biology. Journal of the Royal Statistical Society, 4: $137-170$.

Bashan, Y.; G. Holguin and L. E. de-Bashan (2004). Azospirillum-plant relationships: physiological, molecular, agricultural, and environmental advances. Canadian. J. Microbiol., 50: 521-577.

Belimov , A.A.; A.P. Kojemiakov and C.V. Chuvarliyeva (1995). Interaction between barley and mixed cultures of nitrogen fixing and phosphatesolubilizing bacteria, Plant Soil, 173: 29-37.

Bottini, R.; F.Cassan and P. Piccoli (2004). Nitrogen nutrition of wheat plants gibberellin production by bacteria and its involvement in plant growth promotion and yield increase. Appl. Microbiol. Biotechnol., 65: 497-503.

Copeland, L.O. (1976). Principles of Seed Science and Technology, Burgress Pub. Com., Minneapolis, Minnesota, 164-165.

El-Komy, H. M. A. (2005). Coimmobilization of Azospirillum lipoferum and Bacillus megaterium for successful phosphorus and nitrogen nutrition of wheat plants. Food Technol. Biotechnol., 43 (1):19-27.

Gholami, A.; S. Shahsavani and S. Nezarat (2009). The effect of plant growth promoting rhizobacteria (PGPR) on germination, seedling growth and yield of maize. World Academy of Science, Engineering and Technology, 49:19-24.

Gomez, K.A. and A.A. Gomez (1984). Statistical Producer for Agricultural Research 2nd Ed., John Wiley \& Sons.

ISTA Rules (1999). International Rules for Seed Testing. Seed Science \& Technol. Proc. Int. Seed Test. Ass., 31 (1): 1-152.

Marchner, H. (1995). Mineral Nutrition of Higher Plants (2 ${ }^{\text {nd }}$ ed.), Academic Press, London .

Mirza, M. S.; G. Rasul ; S. Mehnaz ; J. K. Ladha; R. B. So; S. Ali and K. A. Malik (2000). Beneficial effects of inoculated nitrogen-fixing bacteria on rice. In "The Quest for Nitrogen Fixation in Rice" (J. K. Ladha and P. M. Reddy, Eds.) International Rice Research Institute, Los Banos, Philippines, 191-204.

Rodriguez, H. and R. Fraga (1999). Phosphate solubilizing bacteria and their role in plant growth promotion, Biotechnol. Adv., 17: 319-339.

Saikia,S. P.; V. Jain; S. Khetarpal and S. Aravind (2007). Dinitrogen fixation activity of Azospirillum brasilense in maize (Zea mays). Current Science, 93 (9): 1296-1300. 
Scott, S. J.; R. A. Jones and W. A. William (1984). Review of data analysis methods for seed germination. Crop Sci., 24: 1192-1199.

Singh , S. and K.K. Kapoor (1994) .Solubilization of insoluble phosphate by bacteria isolated from different sources, Environ. Ecol., 12: 51-55.

Spaepen, S.; J.Vanderleyden and R. Remans (2007). Indole-3-acetic acid in microbial and microorganism-plant signaling. FEMS Microbiol. Rev., 31: 425-448.

Thuler, D. S.; E. I. S. Floh; W. Handro and H. R. Barbosa (2003). Plant growth regulators and amino acids released by Azospirillum $s p$ in chemically defined media. Lett. Appl. Microbiol., 37: 174-178 (C.F. Computer Search).

Tsavkelova, E. A.; S. Y. Klimova; T. A. Cherdyntseva and A. I. Netrusov (2006). Microbial producers of plant growth stimulators and their practical use: A review. Appl. Biochem. Microbiol., 42: 117-126.

Zou, C.; Z. Li and D. Yu (2010). Bacillus megaterium strain XTBG34 promotes plant growth by producing 2-Pentylfuran. The Journal of Microbiology, 48 (4): 460-466.

كفاءة التسميد الحيوى في تقليل استخدام السماد النيتروجينى وتأثيره على الاتبـات

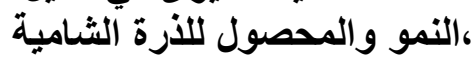

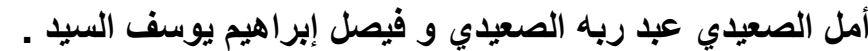

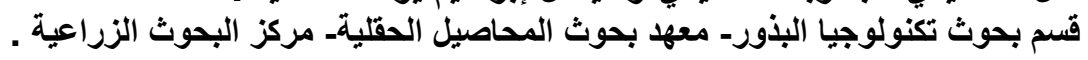

أجريت تجربة معملية بمعمل قسم بحوث تكنولوجيا البذور بالمنصورة خلال البكام عام

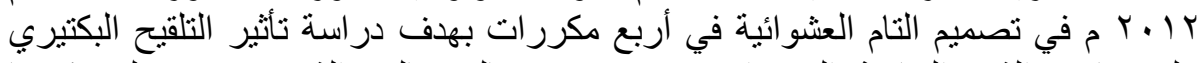

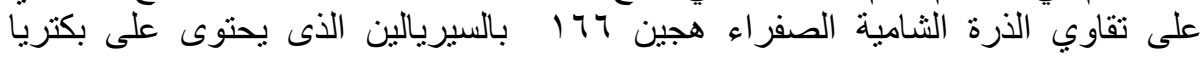

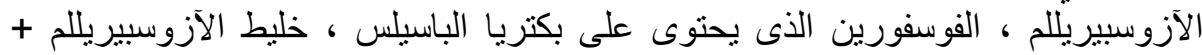

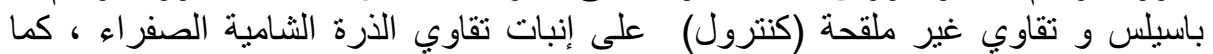

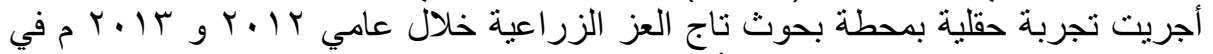

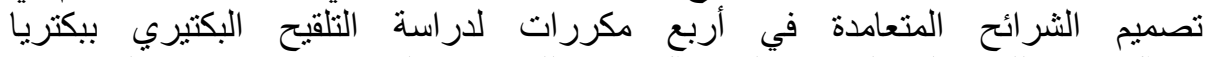

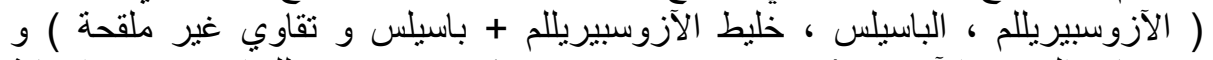

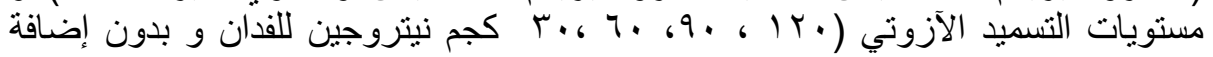

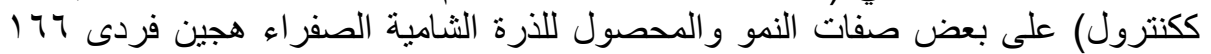

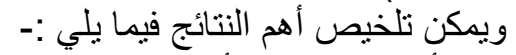

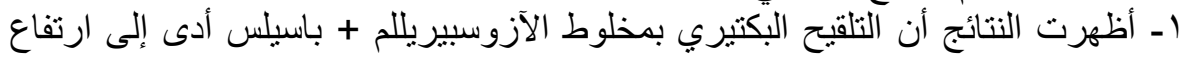

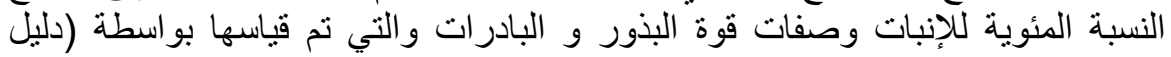

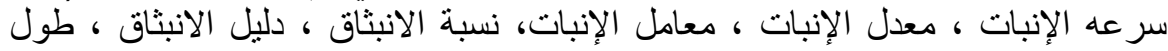

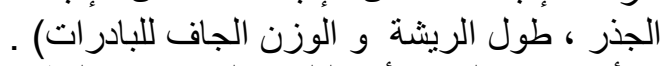

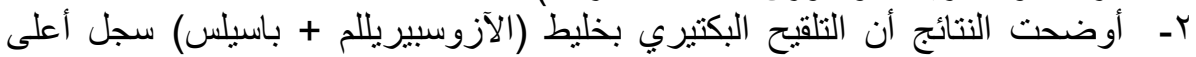

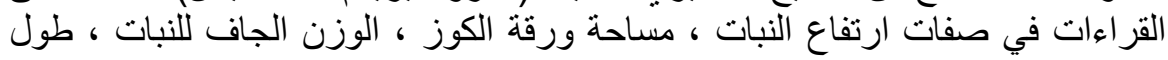

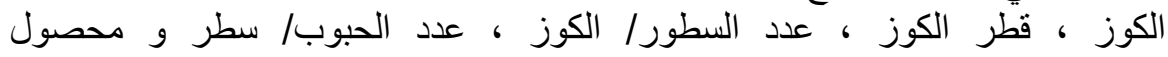
الحبوب/فدان مقارنة بالتقاوي الغير ملقحة. 


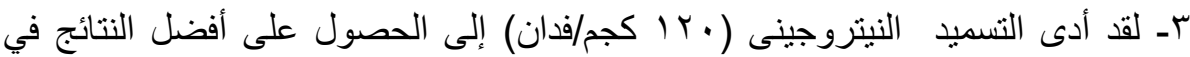
صفات النمو و المحصول السالف ذكرها.

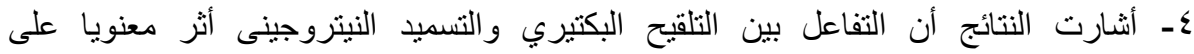

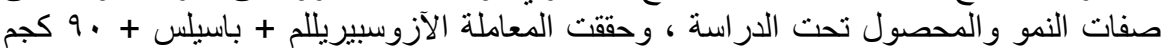

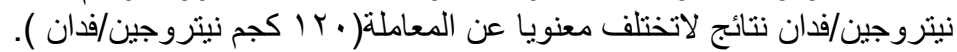

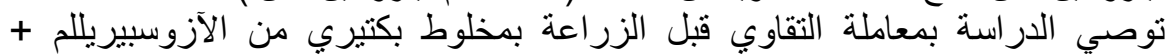

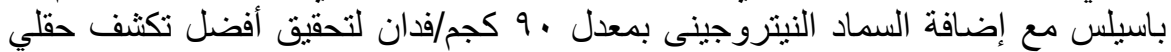
و الحصول على أعلى إنتاجية لمحصول الذرة الثنامية الصفر اء.

كلية الزراعة - جامعة المنصورة قام بتحكيم البحث كلية الزراعة - جامعة الزقازيق جامعة المنصو

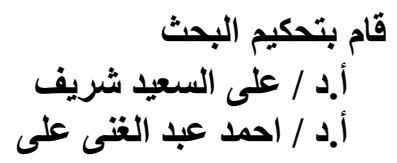

